\title{
Action of Multiple Cell Wall-Degrading Enzymes Is Required for Elicitation of Innate Immune Responses During Xanthomonas oryzae pv. oryzae Infection in Rice
}

\author{
Lavanya Tayi, ${ }^{1}$ Roshan Maku, ${ }^{1}$ Hitendra Kumar Patel, ${ }^{1}$ and Ramesh V. Sonti ${ }^{1}$ \\ ${ }^{1}$ CSIR-Centre for Cellular and Molecular Biology, Uppal Road, Hyderabad, Telangana State, India
}

Accepted 28 May 2016.

\begin{abstract}
Xanthomonas oryzae pv. oryzae secretes a number of plant cell wall-degrading enzymes (CWDEs) whose purified preparations induce defense responses in rice. These defense responses are suppressed by $X$. oryzae pv. oryzae using type 3 secretion system (T3SS) effectors and a type 3 secretion system mutant $\left(\mathrm{T3SS}^{-}\right.$) of $X$. oryzae pv. oryzae is an inducer of rice defense responses. We assessed the role of individual CWDEs in induction of rice defense responses during infection, by mutating them in the genetic background of a T3SS $^{-}$. We mutated the genes for five different plant CWDEs secreted by $X$. oryzae $\mathrm{pv}$. oryzae, including two cellulases ( $c l s A$ and $c b s A)$, one xylanase (xyn), one pectinase (pglA), and an esterase (lipA), singly in a T3SS $^{-}$background. We have demonstrated that, as compared with a $\mathrm{T}_{3 S S^{-}}$of $X$. oryzae pv. oryzae, a $\operatorname{cbs} A^{-} \mathrm{T}_{3 S S^{-}}$, a cls $A^{-} \mathrm{T}_{3 S S}{ }^{-}$, and $a x y n^{-} \mathrm{T}_{3 S S}^{-}$are deficient in induction of rice immune responses such as callose deposits and programmed cell death. In comparison, a $\operatorname{lipA}^{-} \mathrm{T} \mathrm{SS}^{-}$and a $\mathrm{pglA}^{-} \mathrm{T}^{-} \mathrm{SS}^{-}$is as efficient in induction of host defense responses as a T3SS $^{-}$. Overall, these results indicate that the collective action of $X$. oryzae $\mathrm{pv}$. oryzae-secreted ClsA, CbsA, and Xyn proteins is required for induction of rice defense responses during infection.
\end{abstract}

Plants are constantly exposed to a wide range of potential pathogens. Due to the lack of mobile defender cells and an adaptive immune system, plants depend upon the powerful inducible innate immunity of each cell to fight against pathogens that show diverse strategies to survive within the host (Jones and Dangl 2006). The first step in inducible defenses is perception of a pathogen in the vicinity and elicitation of pathogen triggered immunity (PTI), wherein conserved microbial- or pathogen-associated molecular patterns (MAMPs or PAMPs) and damage-associated molecular patterns (DAMPs) released upon damage caused by the pathogen to the host are perceived by transmembrane pattern recognition receptors on the host cell membrane to initiate defense responses (Chisholm et al. 2006). PTI is suppressed by successful pathogens, using effectors that are directly secreted into the host cells via the type 3 secretion system (T3SS) (Büttner and He 2009). Bacterial mutants lacking functional T3SS are virulence-deficient, suggesting a key role of T3SS secreted effectors in pathogenicity (Alfano and Collmer 2004).

Corresponding author: R. V. Sonti; E-mail: sonti@ccmb.res.in

*The $\boldsymbol{e}$-Xtra logo stands for "electronic extra" and indicates that one supplementary figure and one supplementary table are published online.

(c) 2016 The American Phytopathological Society
The T3SS mutant $\left(\mathrm{T}_{3} \mathrm{SS}^{-}\right.$) strains of pathogens like Xanthomonas campestris pv. vesicatoria, Pseudomonas syringae pv. phaseolicola, and Pseudomonas syringae pv. tomato DC3000 have been shown to induce cell wall-associated basal defenses, like deposition of callose and lignin (Bartetzko et al. 2009; Bestwick et al. 1995; Hauck et al. 2003). Transient as well as transgenic expression of T3SS effectors have been shown to suppress defense responses induced by PAMPs and DAMPs as well as defenses induced by $\mathrm{T} \mathrm{SS}^{-}$strains that, presumably, produce PAMPs and DAMPs (Hauck et al. 2003; Keshavarzi et al. 2004; Li et al. 2005; Sinha et al. 2013).

As part of their virulence repertoire, gram-negative plantpathogenic bacteria secrete a wide range of plant cell walldegrading enzymes (CWDEs), such as cellulases, pectinases, xylanases, and proteases, using a type 2 secretion system (T2SS) (Barras et al. 1994; Jha et al. 2005; Kang et al. 1994). Mutational studies clearly indicated that the CWDEs and the T2SS are important virulence determinants of the pathogen (Gough et al. 1988; Kang et al. 1994; Ray et al. 2000). Action of these CWDEs on the wall results in release of endogenous oligosaccharide molecules that are sensed by the host and lead to induction of immune responses. Elicitor activity to the oligosaccharides was reported almost four decades ago by Albersheim and his colleagues (1984), who have demonstrated that hepta $\beta$-glucosyl fragments released from the pathogenic fungal cell walls by the action of plant hydrolytic enzymes are elicitors of phytoalexins (antimicrobial compounds) in the soybean cultures (Darvill and Albersheim 1984). Later on, oligogalacturonide (OG) fragments of the plant cell wall released by the action of pectinases and fragments of fungal cellwall polysaccharide chitin were also shown to be potent inducers of plant defense responses (Ryan and Farmer 1991). A number of studies have shown that purified preparations of the CWDEs secreted by pathogens induce defense responses in plants. To mention a few, Erwinia carotovora pv. carotovora secreted pectic enzymes, including an endopolygalacturonase and two pectate lyases, work collectively with a cellulase to induce expression of a pathogenesis-related gene $\beta, 1-3$ glucanase in tobacco (Vidal et al. 1998). Cellulase treatment in sweet pepper increased endogenous levels of salicylic acid (a defense hormone) and conferred resistance to mild mottle virus attack (Sato et al. 2011). OGs, particularly of degree of polymerization 10-15, released from the homogalacturonan part of pectin, induce various defense responses and protect Arabidopsis against infection by Botrytis cinerea, a necrotrophic fungus (Galletti et al. 2009). Are these defense responses that are induced by purified CWDEs relevant to in vivo conditions? This question arises because, in vivo, the CWDEs may not be produced at the same concentrations as they have been used in the 
purified preparations. Therefore, despite the well-established action of purified preparations of CWDEs in induction of immune responses, we do not know whether these enzymes do, indeed, induce defense responses during infection. We addressed this issue in the interaction between Xanthomonas oryzae pv. oryzae and its host, the rice plant.

$X$. oryzae pv. oryzae causes bacterial leaf blight, a serious rice disease. This bacterium secretes a cocktail of CWDEs, including cellulases, xylanases, lipase/esterase, and more, using a T2SS (Jha et al. 2007; Rajeshwari et al. 2005). Purified prep-

A
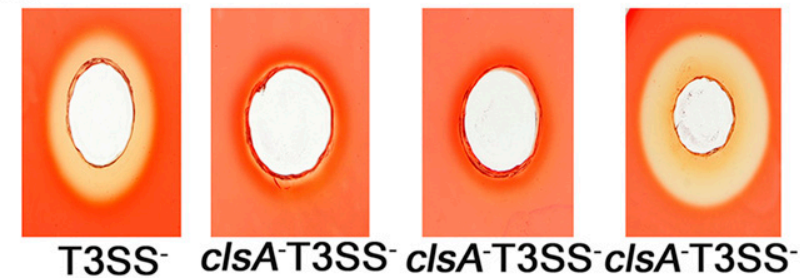
+pHM1 +pHM1::clsA

B

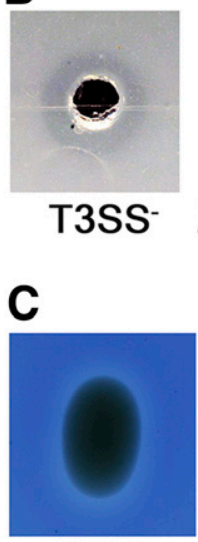

T3SS
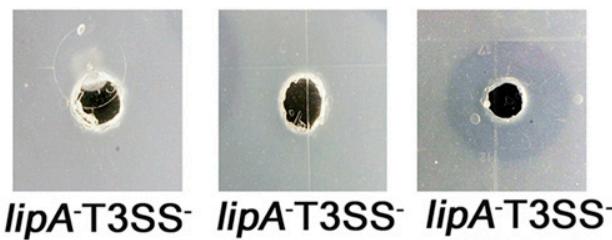
+ pHM1 +pHM1::lipA

D
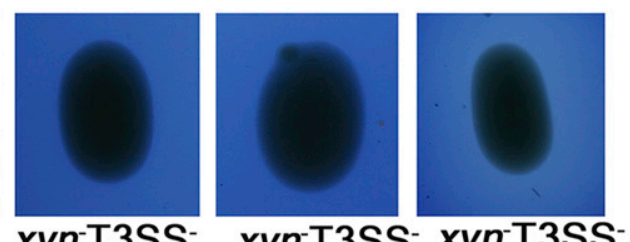
xyn-T3SS- $x y n$-T3SS +pHM1 +pHM1::xyn
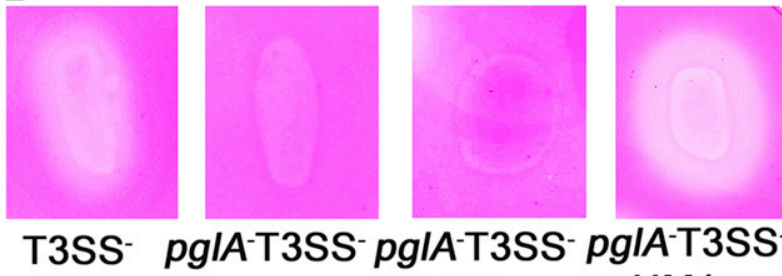
+ pHM1 +pHM1::pglA

Fig. 1. Phenotypes of mutations in genes for specific cell wall-degrading enzymes. A, Endoglucanase assay on carboxymethyl cellulose (CMC) substrate. Culture supernatants of Xanthomonas oryzae pv. oryzae strains $\mathrm{T}_{3 S^{-}}$(type 3 secretion system mutant), $c l s A^{-} \mathrm{T}^{-} \mathrm{SS}^{-}, c l s A^{-} \mathrm{T} 3 \mathrm{SS}^{-} / \mathrm{pHM} 1$, and $c l s A^{-} \mathrm{T}_{3 \mathrm{SS}} / \mathrm{pHM} 1+c l s A$ were loaded in the wells present in agar containing CMC. A halo surrounding the well indicates the presence of active protein in the sample. B, Esterase activity on tributyrin substrate. Culture supernatants of $X$. oryzae pv. oryzae strains $\mathrm{T}_{3} \mathrm{SS}^{-}, \operatorname{lip} A^{-} \mathrm{T}_{3} \mathrm{SS}^{-}$,

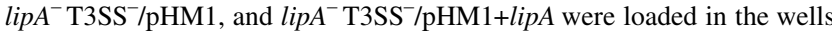
present in agar containing tributyrin. A halo around the well indicates substrate clearance by active protein in the sample. $\mathbf{C}$, Xylanase activity on RBB-xylan substrate. X. oryzae pv. oryzae strains $\mathrm{T} \mathrm{SS}^{-}, x^{-} n^{-} \mathrm{T}^{-} \mathrm{SS}^{-}, x y n^{-}$ $\mathrm{T}_{3 \mathrm{SS}} / \mathrm{pHM} 1$, and $x y n^{-} \mathrm{T}_{3 \mathrm{SS}} / \mathrm{pHM} 1+x y n$ were patched onto a peptone sucrose agar plate containing RBB-xylan. Presence of a halo around the colony is indicative of xylanase proficiency. $\mathbf{D}$, Pectinase activity on Napolygalacturonic acid (PGA) substrate. $X$. oryzae pv. oryzae strains $\mathrm{T}^{-} \mathrm{SS}^{-}$, pglA ${ }^{-} \mathrm{T}_{3} \mathrm{SS}^{-}, p g l A^{-} \mathrm{T} 3 \mathrm{SS}^{-} / \mathrm{pHM} 1$, and $p g l A^{-} \mathrm{T} 3 \mathrm{SS}^{-} / \mathrm{pHM} 1+p g l A$ were patched on PSA plate containing PGA. The presence of a halo around the colony indicates pectinase proficiency. arations of $X$. oryzae pv. oryzae-secreted cellulase (ClsA), cellobiosidase (CbsA), and an esterase (LipA) have been shown to induce defense responses in rice (Jha et al. 2007). These defense responses were suppressed by some of the T3SS effectors of Xanthomonas oryzae pv. oryzae (Sinha et al. 2013). A $\mathrm{T} \mathrm{SS}^{-}$of $X$. oryzae pv. oryzae has been shown to induce defense responses like callose deposition in rice leaves and programmed cell death (PCD) in rice roots. A T2SS/T3SS double mutant is deficient in induction of these defense responses, suggesting a role for T2SS proteins in induction of defense responses during infection (Jha et al. 2007).

In this study, we assessed the role of five major plant CWDEs secreted by Xanthomonas oryzae pv. oryzae-two cellulases, including an endoglucanase (ClsA) and an exoglucanase (CbsA), one xylanase (Xyn), one pectinase (PglA), and an esterase (LipA) - in induction of host innate immunity during infection. We generated mutations in the genes for each of these five enzymes singly in the genetic background of a $\mathrm{T} \mathrm{SS}^{-}$of $X$. oryzae pv. oryzae. We observed that the ClsA, CbsA, and Xyn proteins, indeed, have a role in inducing defense responses during infection, as mutations in genes for any of these three enzymes drastically affected the ability of a $\mathrm{T}_{3 S^{-}}{ }^{-}$to induce defense responses. This is the first report showing the in vivo role of any CWDE in induction of defense responses during infection.

\section{RESULTS}

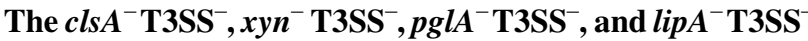
strains are deficient in the enzyme activities.

The culture supernatants of $c l s A^{-} \mathrm{T}_{3} \mathrm{SS}^{-}$and $l i p A^{-} \mathrm{T} 3 \mathrm{SS}^{-}$ double mutant strains are deficient in acting on their respective substrates carboxy methyl cellulose and tributyrin as compared with a $\mathrm{T}_{3} \mathrm{SS}^{-}$mutant, in the plate assays performed. The culture supernatant of $\mathrm{T}_{3} \mathrm{SS}^{-}$produced a zone of clearance, around the well in agarose plates containing the substrate, in which mutants were inefficient in substrate clearance, indicating loss of enzyme activity. The supernatants of the complementing clones $c l s A^{-} \mathrm{T}_{3} \mathrm{SS}^{-} / \mathrm{pHM} 1+c l s A$ and $l i p A^{-} \mathrm{T}^{2} \mathrm{SS}^{-} / \mathrm{pHM} 1+l i p A$ showed a halo (substrate clearance) as $\mathrm{T}^{-} \mathrm{SS}^{-}$(Fig. 1A and B).

Similarly, the $x y n^{-} \mathrm{T}_{3 S S^{-}}$and $p g l A^{-} \mathrm{T}_{3} \mathrm{SS}^{-}$double mutant strains are deficient in acting on their respective substrates, Remazol brilliant blue (RBB)-xylan and Na-polygalacturonic acid (PGA), as compared with a $\mathrm{T}_{3} \mathrm{SS}^{-}$strain. The $\mathrm{T}^{-} \mathrm{SS}^{-}$produced a zone of clearance around the colony on peptone sucrose agar (PSA) plates containing the substrate, whereas mutants were inefficient in substrate clearance, indicating loss of enzyme activity. The complementing clones $x y n^{-} \mathrm{T}_{3} \mathrm{SS}^{-} / \mathrm{pHM} 1+x y n$ and $p g l A^{-} \mathrm{T}_{3} \mathrm{SS}^{-} / \mathrm{pHM} 1+p g l A$ produced a similar halo (substrate clearance) as the $\mathrm{T}^{-} \mathrm{SS}^{-}$, while the strains with empty vector, $x y n{ }^{-} \mathrm{T}_{3} \mathrm{SS}^{-} / \mathrm{pHM} 1$ and $p g l A^{-} \mathrm{T}_{3 \mathrm{SS}} / \mathrm{pHM} 1$, did not show any activity (Fig. 1C and D)

Sodium dodecyl sulfate-polyacrylamide gel electrophoresis (SDS-PAGE) analysis of the culture supernatant of the T3SS mutant shows CbsA protein along with other proteins like LipA and ClsA (Supplementary Fig. S1-d). The culture supernatant of the $c b s A^{-} \mathrm{T}_{3} \mathrm{SS}^{-}$strain lacks the CbsA protein. The SDS-PAGE profile of the strain with the complementing clone $\left(c b s A^{-} \mathrm{T}_{3 S S^{-}} / \mathrm{pHM} 1+c b s A\right)$ indicates restoration of CbsA protein production. The $c b s A^{-} \mathrm{T} 3 \mathrm{SS}^{-} / \mathrm{pHM} 1$ exhibits a protein profile that is similar to the profile of the $c b s A^{-} \mathrm{T}_{3} \mathrm{SS}^{-}$mutant.

\section{X. oryzae pv. oryzae secreted cellulases CbsA and ClsA} are inducers of defense responses during infection.

Callose deposition is considered as an innate immune response that strengthens the cell wall at the site of pathogen entry. Callose deposition was assessed after infiltration of rice leaves with the following $X$. oryzae pv. oryzae strains: $\mathrm{T}_{3} \mathrm{SS}^{-}$, 
$c b s A^{-} \mathrm{T}_{3} \mathrm{SS}^{-}$double mutant, $c b s A^{-} \mathrm{T}^{2} \mathrm{SS}^{-} / \mathrm{pHM} 1$ (empty vector control), $c b s A^{-} \mathrm{T}_{3 \mathrm{SS}} / \mathrm{pHM} 1+c b s A$ (complementing clone), $c l s A^{-} \mathrm{T}_{3} \mathrm{SS}^{-}$double mutant, $c l s A^{-} \mathrm{T} 3 \mathrm{SS}^{-} / \mathrm{pHM} 1$ (empty vector control), $c l s A^{-} \mathrm{T}_{3 \mathrm{SS}} / \mathrm{pHM} 1+c l s A$ (complementing clone), and BXO43 (wild type [wt]). A T3SS ${ }^{-}$deficient strain of $X$. oryzae pv. oryzae has been shown to be an inducer of innate immune responses in rice (Jha et al. 2007). This has been attributed to its reduced ability to suppress host immune responses. Rice leaves infiltrated with a $\mathrm{T} \mathrm{SS}^{-}$strain (Fig. 2A and B) exhibited a higher number of callose spots as compared with the BXO43 (wt) strain (Fig. 2A and B), whereas the rice leaves infiltrated with the $c b s A^{-} \mathrm{T}_{3 S^{-}}$and $c l s A^{-} \mathrm{T}_{3} \mathrm{SS}^{-}$strains exhibited significantly lesser number of callose deposits (Fig. 2A and B). This clearly suggested that deleting either a $c l s A$ or $c b s A$ gene in a $\mathrm{T}_{3} \mathrm{SS}^{-}$strain has drastically affected the ability of the $\mathrm{T} \mathrm{SS}^{-}$to induce callose deposition in rice leaves. The strains with the complementing clones $\left(c b s A^{-} \mathrm{T}_{3} \mathrm{SS}^{-} / \mathrm{pHM} 1+c b s A\right.$ and $c l s A^{-} \mathrm{T}_{3 \mathrm{SS}^{-}} / \mathrm{pHM} 1+c l s A$ ) expressing $c b s A$ and $c l s A$ genes, respectively, from plasmid $\mathrm{pHM} 1$ exhibited a similar number of callose deposits as a T3SS ${ }^{-}$mutant (Fig. 2A and B). Infiltration of control strains carrying only the vector $\left(c b s A^{-} \mathrm{T}_{3} \mathrm{SS}^{-} / \mathrm{pHM} 1\right.$ and $\left.c l s A^{-} \mathrm{T}_{3 \mathrm{SS}} / \mathrm{pHM} 1\right)$ resulted in callose deposition that was at the same level as that observed with $c b s A^{-} \mathrm{T}_{3 S^{-}}$and $c l s A^{-} \mathrm{T}_{3} \mathrm{SS}^{-}$ (Fig. 2A and B).

Jha et al. (2007) have also shown that the $X$. oryzae pv. oryzae $\mathrm{T}_{3} \mathrm{SS}^{-}$induces PCD in rice roots. We assessed the role of ClsA and CbsA proteins in the induction of PCD by the T3SS ${ }^{-}$. The assay for PCD was the internalization of propidium iodide (PI). In living plant cells, PI stains the cell wall while it is internalized and stains nucleic acids in cells undergoing PCD. Rice roots were treated with cultures of the following $X$. oryzae pv. oryzae strains: T3SS ${ }^{-}$, BXO43 (wt), $c b s A^{-} \mathrm{T}^{-} \mathrm{SS}^{-}$double mutant, $c b s A^{-} \mathrm{T}^{-} \mathrm{SS}^{-} / \mathrm{pHM} 1$ (empty vector control), $c b s A^{-} \mathrm{T}_{3} \mathrm{SS}^{-} / \mathrm{pHM} 1+c b s A$ (complementing strain), $c l s A^{-} \mathrm{T}_{3 S^{-}}$double mutant, $c l s A^{-} \mathrm{T} \mathrm{SS}^{-} / \mathrm{pHM} 1$ (empty vector control), and $c l s A^{-} \mathrm{T}_{3 \mathrm{SS}} / \mathrm{pHM} 1+\mathrm{clsA}$ (complementing strain). Cells of rice roots treated with $\mathrm{T} \mathrm{SS}^{-}$showed extensive internalization of PI (Fig. 3A). The PI staining material was dispersed within the cells, suggesting nuclear fragmentation as a consequence of PCD. In comparison, the BXO43 (wt)-treated roots showed only cell wall-bound PI staining (Fig. 3B). The $c b s A^{-} \mathrm{T}^{2} \mathrm{SS}^{-}$double mutant and the $c l s A^{-} \mathrm{T}_{3} \mathrm{SS}^{-}$double mutant treated roots did not exhibit PI internalization, indicating that

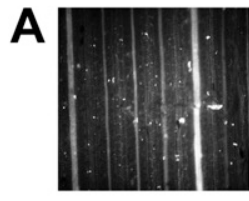

T3Ss-

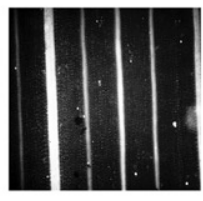

cbsA-T3SS

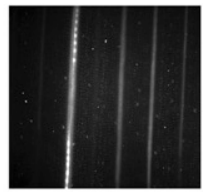

cbsA-T3SS+pHMI

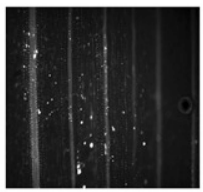

cbsA-T3SS+ pHM1::cbsA

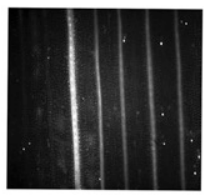

BXO43 (Wt)
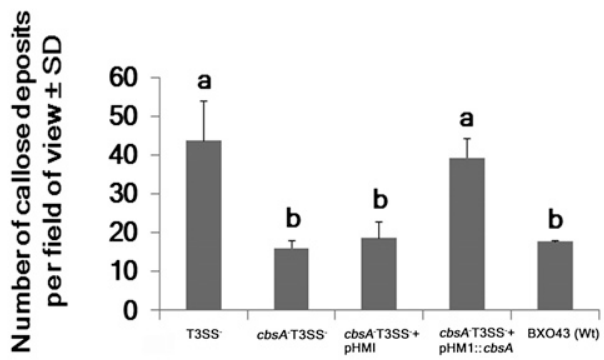

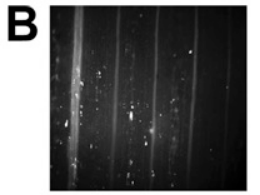

T3SS

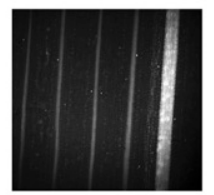

cIsA'T3SS-

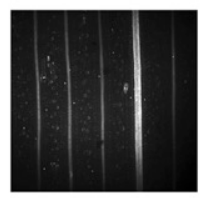

clsA-T3SS-+pHMI

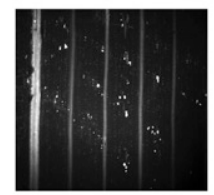

clsA-T3SS+ pHM1::clsA

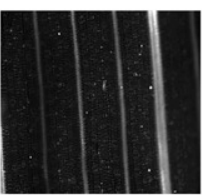

BXO43 (Wt)

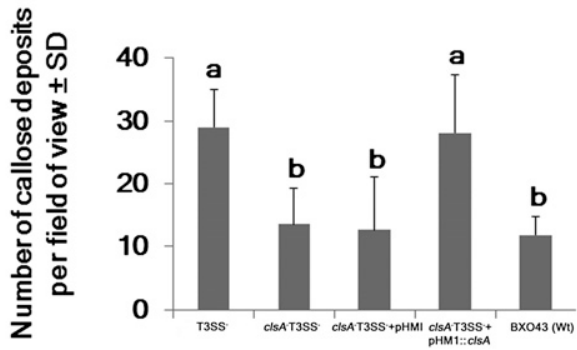

Fig. 2. The $c b s A^{-}$and $c l s A^{-}$type 3 secretion system-negative mutants ( $\mathrm{T} \mathrm{SS}^{-}$) of Xanthomonas oryzae pv. oryzae are deficient in induction of callose deposition in rice leaves. A, Ten- to 15 -day-old rice leaves were infiltrated with one of the following strains of $X$. oryzae pv. oryzae: $\mathrm{T}_{3 \mathrm{SS}}^{-}, c b s A^{-} \mathrm{T}^{-} \mathrm{SS}^{-}$double mutant, $c b s A^{-}$ $\mathrm{T}^{2} \mathrm{SS}^{-} / \mathrm{pHM} 1$ (empty vector control), $c b s A^{-} \mathrm{T}_{3 \mathrm{SS}} / \mathrm{pHM} 1+c b s A$ (complementing clone), or BXO43 (wild type [wt]). B, Similarly, rice leaves were also infiltrated with one of the following strains of $X$. oryzae pv. oryzae: $\mathrm{T}^{2} \mathrm{SS}^{-}, c l s A^{-} \mathrm{T} 3 \mathrm{SS}^{-}$double mutant, $c l s A^{-} \mathrm{T} 3 \mathrm{SS}^{-} / \mathrm{pHM}$ (empty vector control), $c l s A^{-}$ $\mathrm{T}_{3 \mathrm{SS}} / \mathrm{pHM} 1+c l s A$ (complementing clone), or BXO43 (Wt). The leaves were subsequently stained with aniline blue and were visualized under an epifluorescence microscope. Bright spots in the images are the callose deposits. The graphs illustrate the average number of callose spots from at least four leaves and three to four different viewing areas plotted in each experiment. Error bars represent standard deviation. A student's two-tailed $t$ test for independent means was performed in pairwise combinations for all the values. Values with the same letter (either a or b) are not significantly different at the $P<0.05$ level. Similar results were obtained in three independent experiments. 
these strains do not induce cell death (Fig. 3C and D). Roots treated with the complementing strains $c b s A^{-} \mathrm{T}_{3} \mathrm{SS}^{-} / \mathrm{pHM} 1+$ $c b s A$ and $c l s A^{-} \mathrm{T}_{3} \mathrm{SS}^{-} / \mathrm{pHM} 1+c l s A$ exhibited extensive PI internalization, indicating that they are restored in the ability to

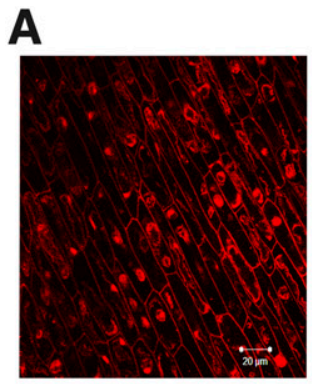

T3SS-

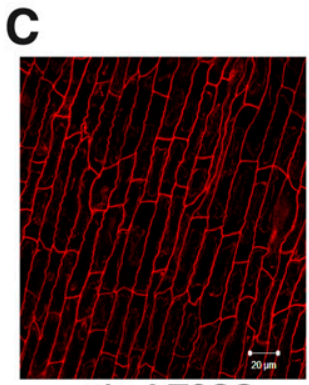

$\operatorname{cbs} A^{-T}$ TSS
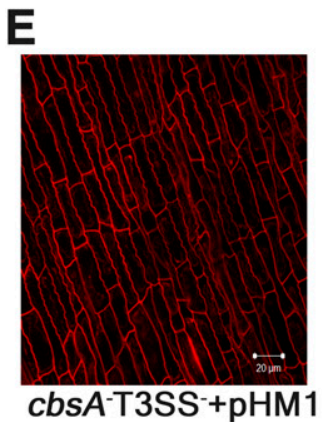

G

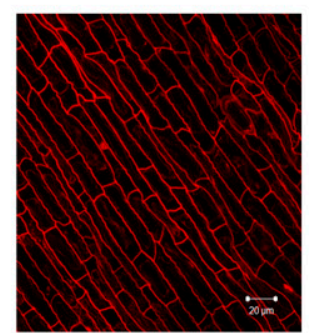

clsA-T3SS-+pHM1

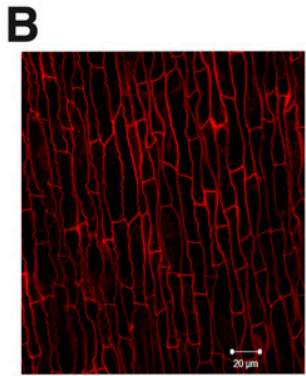

$\mathrm{BXO43}(\mathrm{Wt})$

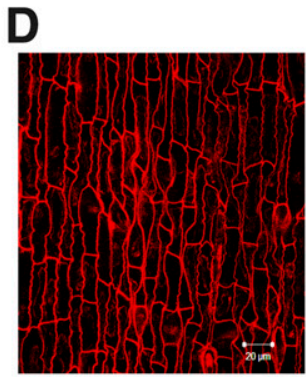

clsA-T3SS

$\mathbf{F}$

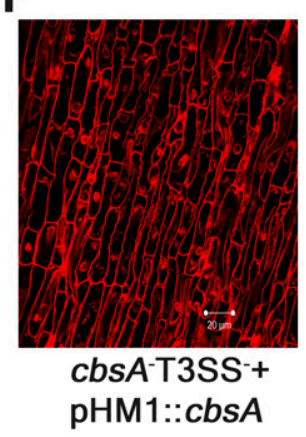

H

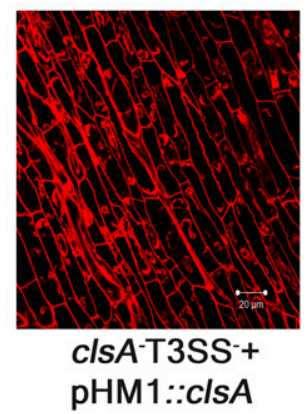

Fig. 3. The $c b s A^{-}$and $c l s A^{-}$type 3 secretion system-negative mutants (T3SS ${ }^{-}$) of Xanthomonas oryzae pv. oryzae are deficient in induction of programmed cell death (PCD) in rice roots. Rice roots were treated with one of the following strains of $X$. oryzae pv. oryzae: A, T3SS - , B, BXO43 (Wt), C, $c b s A^{-} \mathrm{T}_{3} \mathrm{SS}^{-}$double mutant, D, cls $A^{-} \mathrm{T}_{3 S S^{-}}$double mutant, E, $c b s A^{-}$ $\mathrm{T}_{3 \mathrm{SS}} / \mathrm{pHM} 1$ (empty vector control), $\mathbf{F}, c b s A^{-} \mathrm{T}^{-} \mathrm{SS}^{-} / \mathrm{pHM} 1+c b s A$ (complementing clone), $\mathbf{G}, c l s A^{-} \mathrm{T} 3 \mathrm{SS}^{-} / \mathrm{pHM} 1$ (empty vector control), or $\mathbf{H}$, $c l s A^{-} \mathrm{T} 3 \mathrm{SS}^{-} / \mathrm{pHM} 1+c l s A$ (complementing clone). Following treatment, the roots were stained with propidium iodide $(\mathrm{PI})$ and were visualized under a confocal microscope. Internalization and dispersion of PI inside the cells is indicative of PCD. Scale bar measures $20 \mu \mathrm{m}$. induce $\mathrm{PCD}$ (Fig. 3F and $\mathrm{H}$ ). The rice roots treated with the control strains $c b s A^{-} \mathrm{T} 3 \mathrm{SS}^{-} / \mathrm{pHM} 1$ and $c l s A^{-} \mathrm{T} 3 \mathrm{SS}^{-} / \mathrm{pHM} 1$ do not exhibit internalization of PI and exhibit PI staining only in the wall (Fig. 3E and G).

\section{Xylanase is also required for induction of immune} responses by a $\mathrm{T3SS}^{-}$strain of $X$. oryzae pv. oryzae.

Having observed that cellulases are essential for induction of defense responses under in vivo conditions, we proceeded to assess the role of the major xylanase in induction of innate immunity during infection. For this purpose, we generated in frame deletion in the xylanase encoding gene (xyn) of X. oryzae pv. oryzae in a T3SS mutant background and assessed the ability of the $x y n^{-} \mathrm{T}_{3} \mathrm{SS}^{-}$ double mutant strain to induce PCD and callose deposition.

The PCD assay was performed in rice roots, as mentioned below, with the following strains of $X$. oryzae pv. oryzae: T3SS ${ }^{-}$, $x y n^{-} \mathrm{T} \mathrm{SS}^{-}$double mutant, $x y n^{-} \mathrm{T}^{-} \mathrm{SS}^{-} / \mathrm{pHM} 1$ (empty vector control), $x y n^{-}{ }^{-} \mathrm{T}_{\mathrm{SS}}{ }^{-} / \mathrm{pHM} 1+x y n$ (complementing strain), and BXO43 (wt). As expected, the T3SS ${ }^{-}$induced PCD in rice roots (Fig. 4B), whereas mutation of the xyn gene (which is responsible for the major xylanase activity under laboratory conditions) affected the ability of $\mathrm{T} \mathrm{SS}^{-}$to induce PCD in rice roots. Rice roots treated with the $x y n^{-} \mathrm{T}_{3 S^{-}}$double mutant showed no PI internalization and nuclear fragmentation (Fig. 4B). Expression of this gene product in the mutant, i.e., the complementing strain $x y n^{-} \mathrm{T}_{3 \mathrm{SS}^{-}} / \mathrm{pHM} 1+x y n$ has restored the PCD-inducing capacity (Fig. 4B). The $x y n^{-} \mathrm{T}^{-} \mathrm{SS}^{-}$double mutant with the empty pHM1 vector does not induce any PCD, as only cell wall-bound PI staining is seen (Fig. 4B).

The effect of mutation in the $x y n$ gene on the ability of the $\mathrm{T}_{3} \mathrm{SS}^{-}$to induce callose deposition was also assessed. The $x y n^{-} \mathrm{T}^{-} \mathrm{SS}^{-}$double mutant was deficient in inducing callose deposition (Fig. 4A and C). Introduction of the xyn gene using pHM1 plasmid (Fig. 4A and C) but not the control empty pHM1 vector (Fig. 4A and C) restored the ability of the $x y n^{-} \mathrm{T}^{-} \mathrm{SS}^{-}$double mutant to induce callose deposition.

LipA, an esterase secreted by $X$. oryzae pv. oryzae, is not essential for induction of immune responses during infection.

The purified LipA protein has been shown to induce immune responses in rice. To assess its role in eliciting immune responses during infection, a lipA $A^{-} \mathrm{T}_{3} \mathrm{SS}^{-}$double mutant was generated. The $\operatorname{lipA^{-}} \mathrm{T}_{3 S^{-}}$strain is as efficient at inducing callose deposition in leaves as the $\mathrm{T}^{-} \mathrm{SS}^{-}$(Fig. 5B and C). Also, lipA ${ }^{-} \mathrm{T}^{-} \mathrm{SS}^{-}$is as proficient in inducing PCD in roots as the T3SS ${ }^{-}$(Fig. 5A). This suggests that, although purified LipA can induce rice defense responses, it is not essential for elicitation of immune responses during an actual infection condition.

The polygalacturonase PglA has no role in induction of immune responses during infection.

Pectinases are an important class of CWDEs, whose role as key virulence factors of pathogens and as inducers of host defense responses is very well established. PglA is the major pectin-degrading enzyme secreted by $X$. oryzae $p v$. oryzae (L. Tayi and R. V. Sonti unpublished results). To study its ability to induce defense responses under infection conditions, a $p g l A^{-} \mathrm{T}_{3} \mathrm{SS}^{-}$strain was generated and immune response assays were performed. The $p g l A^{-} \mathrm{T}_{3} \mathrm{SS}^{-}$is as efficient in inducing callose deposition in leaves and PCD in roots as the T3SS ${ }^{-}$(Fig. $6 \mathrm{~A}, \mathrm{~B}$, and $\mathrm{C}$ ). This clearly indicates that there is no major role for PglA in eliciting defense responses in rice during infection.

\section{DISCUSSION}

In a previous study, Jha and coworkers (2007) have shown that defense responses are induced in rice tissues upon treatment with 
purified preparations of $X$. oryzae pv. oryzae T2SS secreted proteins ClsA, CbsA, and LipA. They have also demonstrated that a $\mathrm{T}_{3} \mathrm{SS}^{-}$of $X$. oryzae pv. oryzae functions as an inducer of rice innate immunity and a $\mathrm{T}_{2} \mathrm{SS}^{-} \mathrm{T}^{-} \mathrm{SS}^{-}$double mutant is deficient in inducing these defense responses, indicating that T2SS secreted proteins play a key role in the ability of the $\mathrm{T}_{3} \mathrm{SS}^{-}$to induce defense responses in rice (Jha et al. 2007). In the genetic background of $\mathrm{T}_{3} \mathrm{SS}^{-}$, in this study, we made mutations in the genes for each of five T2SS secreted proteins, to study the contribution of these different CWDEs in induction of host defense responses during infection. Our results indicate that two cellulases (ClsA and CbsA) and a xylanase (Xyn) are essential for the ability of a T3SS ${ }^{-}$of $X$. oryzae pv. oryzae to induce immune responses during infection. The loss of any one of these functions affects the ability of a $\mathrm{T}_{3} \mathrm{SS}^{-}$to induce immune responses. In contrast, a secreted lipase/esterase (LipA) and a polygalacturonase (PglA) are not essential for elicitation of immune responses during infection. A double mutant of $c b s A$ and $c l s A$ in $\mathrm{T}_{3} \mathrm{SS}^{-}$background is as defective in induction of defense responses as either of the single mutants $c b s A$ or $c l s A$ in $\mathrm{T}_{3} \mathrm{SS}^{-}$background (L. Tayi and $\mathrm{R}$. V. Sonti unpublished data), indicating that there is no additive effect of deleting both cellulases ClsA and CbsA in cell wall damage-induced defense responses during infection.

Purified preparations of LipA protein have been earlier shown by Jha et al. (2007) to induce defense responses when infiltrated into rice tissues. Mutations in LipA protein affect virulence of $X$. oryzae pv. oryzae (Jha et al. 2007) and, so, it appears that this protein is produced during growth of the

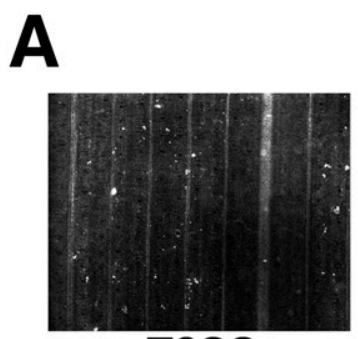

T3SS-

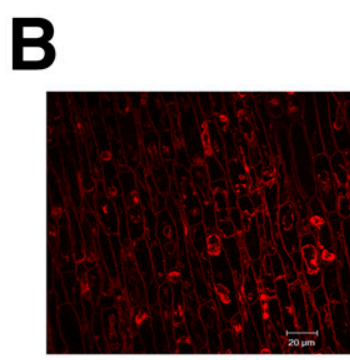

T3SS

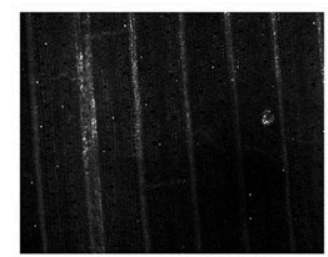

xyn-T3SS

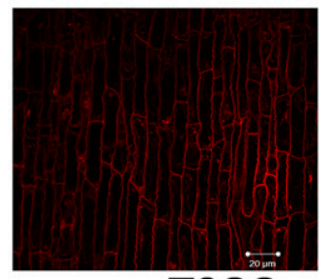

xyn-T3SS

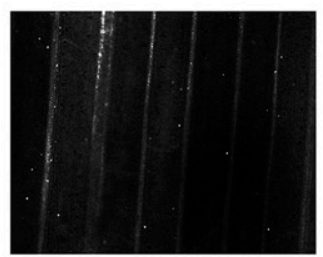

xyn-T3SS-+ pHM1

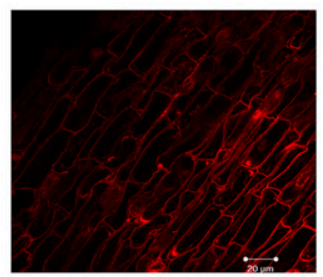

xyn-T3SS++ pHM1

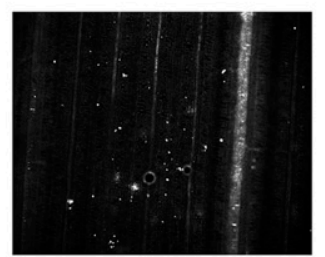

$x y$ T3SS-+ $^{-1}$

pHM1::xyn

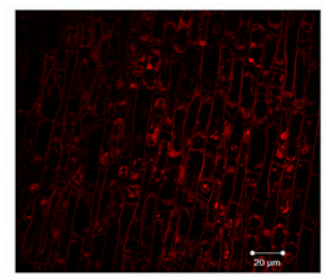

xyn-T3SS-+ pHM1::xyn

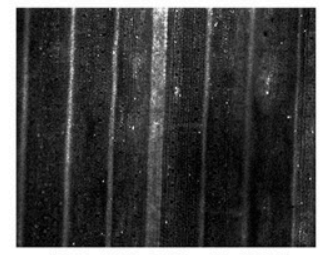

$\mathrm{BXO43}(\mathrm{Wt})$

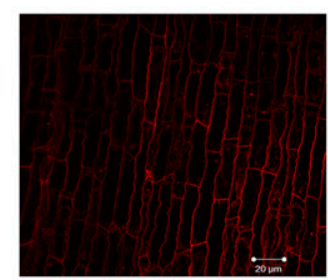

$\mathrm{BXO43}(\mathrm{Wt})$

\section{C}
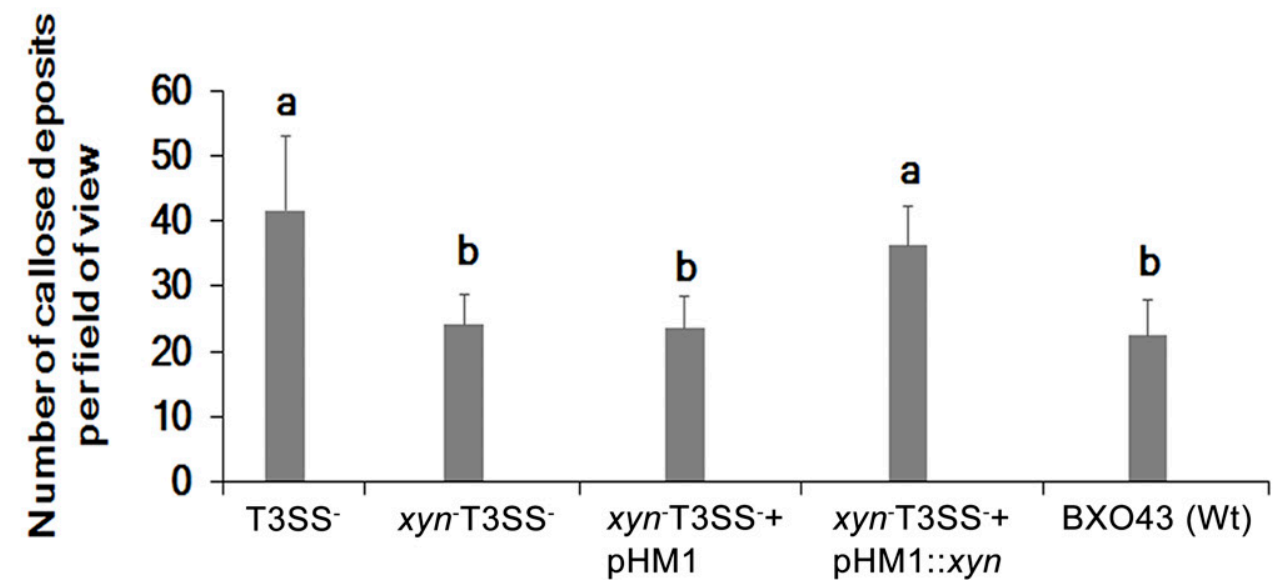

Fig. 4. A $x_{y n}{ }^{-}$type 3 secretion system-negative mutant $\left(\mathrm{T}_{3} \mathrm{SS}^{-}\right)$is deficient in induction of programmed cell death (PCD) in rice roots and callose deposition in rice leaves. A, Rice leaves were treated with one of the following strains of $X$. oryzae pv. oryzae: $\mathrm{T}_{\mathrm{SSS}}^{-}, \mathrm{xyn}^{-} \mathrm{T}^{\mathrm{SSS}}{ }^{-}$double mutant, $x y n^{-} \mathrm{T} 3 \mathrm{SS}{ }^{-} / \mathrm{pHM} 1$ (empty vector control), $x y n^{-} \mathrm{T} 3 \mathrm{SS}^{-} / \mathrm{pHM} 1+x y n$ (complementing clone), or BXO43 (wt). The leaves were subsequently stained with aniline blue and were visualized under an epifluorescence microscope. Bright spots in the images are the callose deposits. B, Rice roots were treated with one of the following strains of X. oryzae pv. oryzae: $\mathrm{T} \mathrm{SS}^{-}, x y n^{-} \mathrm{T} \mathrm{SS}^{-}$double mutant, $x y n^{-} \mathrm{T} 3 \mathrm{SS}^{-} / \mathrm{pHM} 1$ (empty vector control), $x y n^{-} \mathrm{T}^{-} \mathrm{SS}^{-} / \mathrm{pHM}+x y n$ (complementing clone), or BXO43 (Wt). Following treatment, the roots were stained with propidium iodide (PI) and were visualized under a confocal microscope. Internalization and dispersion of PI inside the cells is indicative of PCD. Scale bar measures $20 \mu \mathrm{m}$. C, Mean of the callose counts collected from at least four leaves and three to four different viewing areas from the infiltrated region of each leaf were plotted. Error bars represent standard deviations. Values with the same letter (either a or b) are not significantly different at the $P<0.05$ level in a student's two-tailed $t$ test performed for independent means. Similar results were obtained in three independent experiments. 
pathogen in planta. Therefore, the question arises as to why the LipA protein is not required for elicitation of innate immune responses by the $\mathrm{T}_{3} \mathrm{SS}^{-}$. In this connection, it is important to note that our results merely show that LipA and PglA are not essential for elicitation of innate immunity during infection, as it is possible that their role in elicitation of innate immunity is redundant and that some other functions may substitute for the same.

Purified preparations of ClsA and CbsA can elicit rice immune responses such as callose deposition and PCD (Jha et al. 2007). Purified preparations of Xyn protein elicit PCD in rice (R. Ramanan and R. V. Sonti unpublished results). Paradoxically, it appears that the lack of even one of these enzymes affects the ability to elicit immune responses during infection. We propose that, during infection, the rice plant is monitoring damage caused by multiple CWDEs before a decision is made to mount a defense response. As many as six cellulases, three $\beta$-glucosidases, one cellobiosidase, four xylanases, six xylosidases, one polygalacturonase, three pectin-degrading enzymes
A

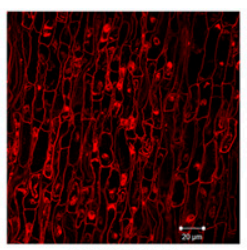

T3SS-

B

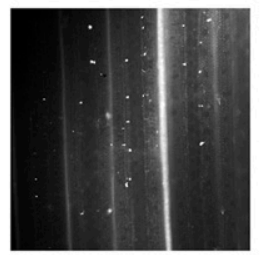

T3SS

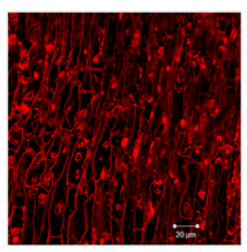

lipA-T3SS-

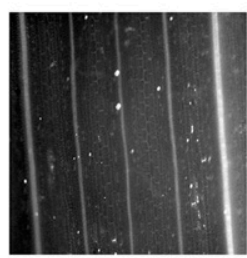

lipA-T3SS

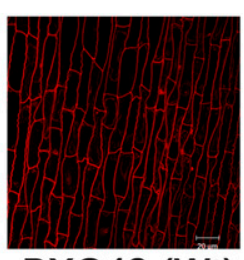

$\mathrm{BXO} 43(\mathrm{Wt})$

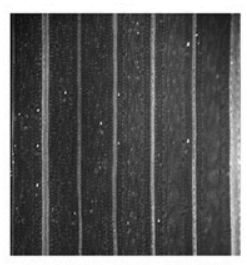

$\mathrm{BXO} 43(\mathrm{Wt})$
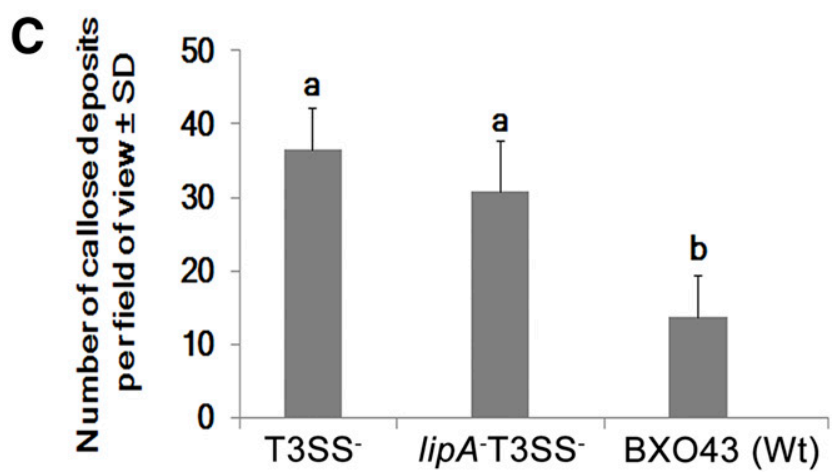

Fig. 5. A $\operatorname{lipA^{-}}$ type 3 secretion system-negative mutant $\left(\mathrm{T}_{3} \mathrm{SS}^{-}\right)$of Xanthomonas oryzae pv. oryzae is proficient in induction of programmed cell death (PCD) in rice roots and callose deposition in rice leaves. A, Rice roots were treated with one of the following strains of $X$. oryzae pv. oryzae: $\mathrm{T}_{3 \mathrm{SS}}{ }^{-}$, lipA ${ }^{-} \mathrm{T}^{-} \mathrm{SS}^{-}$double mutant, or BXO43 (Wt). Following treatment, the roots were stained with propidium iodide (PI) and were visualized under a confocal microscope. Internalization and dispersion of PI inside the cells is indicative of PCD. Scale bar measures $20 \mu \mathrm{m}$. B, Rice leaves were treated with one of the following strains of $X$. oryzae pv. oryzae: $\mathrm{T}_{3} \mathrm{SS}^{-}$, lipA $\mathrm{T}_{3} \mathrm{SS}^{-}$double mutant, or BXO43 (Wt). The leaves were subsequently stained with aniline blue and were visualized under an epifluorescence microscope. Bright spots in the images are the callose deposits. C, Mean and standard deviation were calculated for number of callose deposits from a field of view. Data were collected from at least four leaves in each experiment and three to four different viewing areas from the infiltrated region of each leaf. A student's two-tailed $t$ test for independent means was performed in pairwise combinations for all the values. Values with the same letter (either a or b) are not significantly different at the $P<0.05$ level. Similar results were obtained in three independent experiments. (one pectin methylesterase, two pectate lyases), six proteases, are encoded in the $X$. oryzae pv. oryzae genome (Lee et al. 2005). We have tested the roles of only five such enzymes in elicitation of innate immunity during infection. It is possible that $X$. oryzae pv. oryzae secreted CWDEs other than ClsA, $\mathrm{CbsA}$, and Xyn are involved in elicitation of rice innate immunity during infection.

Cellulases, xylanases, and pectinases have all been shown to elicit defense responses in various plants. In the case of ethylene-inducing xylanase of Trichoderma reesei, enzyme activity is not required and the protein is recognized as a PAMP by the host (Enkerli et al. 1999; Ron and Avni 2004). Recently, a cellulase from Rhizoctonia solani has been shown to be an inducer without the requirement of its enzymatic activity (Ma et al. 2015). However, in a majority of the cases, activity of the CWDE is recognized via the cell wall fragments - the oligosaccharide molecules released by the action of the CWDE on the host cell
A

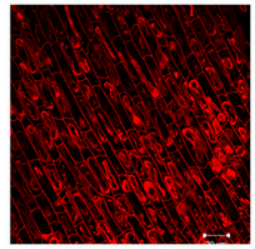

T3SS

B

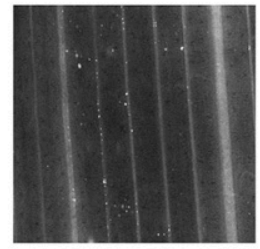

T3SS-

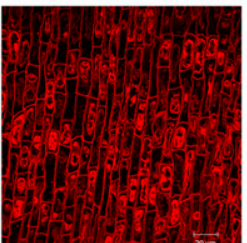

pgIA-T3SS

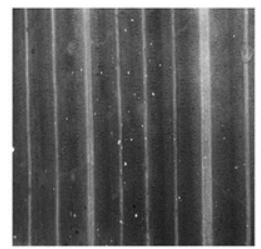

pgIA-T3SS-

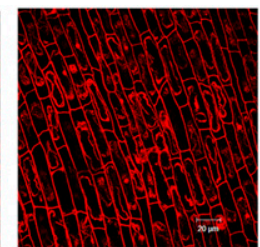

$\mathrm{BXO43}(\mathrm{Wt})$

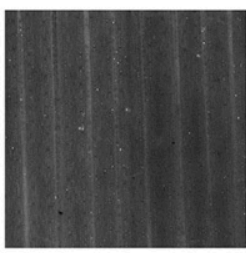

$\mathrm{BXO43}(\mathrm{Wt})$
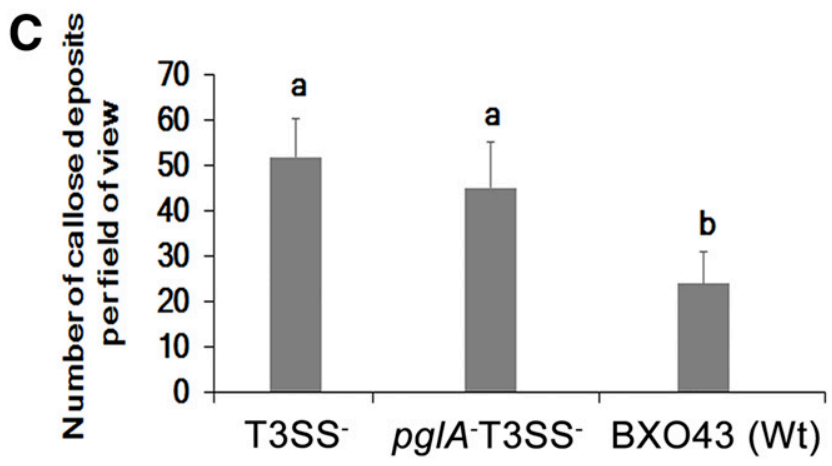

Fig. 6. A pglA ${ }^{-}$type 3 secretion system-negative mutant $\left(\mathrm{T}_{3} \mathrm{SS}^{-}\right)$of Xanthomonas oryzae pv. oryzae is proficient in induction of programmed cell death (PCD) in rice roots and callose deposition in rice leaves. A, Rice roots were treated with one of the following strains of $X$. oryzae pv. oryzae: $\mathrm{T} \mathrm{SS}^{-}, p g l A^{-} \mathrm{T} \mathrm{SS}^{-}$double mutant, or BXO43 (Wt). Following treatment, the roots were stained with propidium iodide $(\mathrm{PI})$ and were visualized under a confocal microscope. Internalization and dispersion of PI inside the cells is indicative of PCD. Scale bar measures $20 \mu \mathrm{m}$. B, Rice leaves were treated with one of the following strains of $X$. oryzae pv. oryzae: $\mathrm{T}_{3} \mathrm{SS}^{-}, \mathrm{pglA}^{-}$ $\mathrm{T} \mathrm{SS}^{-}$double mutant, or BXO43 (Wt). The leaves were subsequently stained with aniline blue and were visualized under an epifluorescence microscope. Bright spots in the images are the callose deposits. C, Mean and standard deviation were calculated for number of callose deposits from a field of view. Data were collected from at least four leaves in each experiment and three to four different viewing areas from the infiltrated region of each leaf. A student's two-tailed $t$ test for independent means was performed in pairwise combinations for all the values. Values with the same letter (either a or b) are not significantly different at the $P<0.05$ level. Similar results were obtained in three independent experiments. 
wall. At least for ClsA and CbsA, Jha et al. (2007) have presented evidence indicating that soluble elicitors that are released by the action of these proteins on crude preparations of rice cell walls are involved in elicitation of innate immunity.

The role of oligosaccharides derived from the cell walls of fungi and plants as potent elicitors of defense signaling cascades is very well established in several plant systems. Hepta $\beta$-glucosides, laminarioligosaccharides, and chitooligosaccharides are well known oligosaccharides of fungal cell-wall origin, whereas OGs are the molecules derived from pectic polysaccharides of the plant cell wall whose role as elicitors of defense responses is best characterized. Oligogalacturonides of degree of polymerization 10-20 appear to be the most active elicitors (Shibuya and Minami 2001). Recently, it has been shown that OGs, indeed, act as DAMPs in planta and induce defense responses. Evidence is provided for in vivo production of OGs in transgenic Arabidopsis expressing a fungal polygalacturonase fused to a plant polygalacturonase-inhibiting protein expressing under pathogen-inducible promoter. This chimeric construct-expressing plant is shown to be resistant to Botrytis cinerea, Pectobacterium carotovorum, and Pseudomonas syringae (Benedetti et al. 2015).

Based on our results, we hypothesize that, during infection, the damage caused to the cell wall by the activity of a single enzyme may not be sufficient to mount defense responses and that cooperativity among different classes of CWDEs is required for induction of defense responses. The two cellulases, CbsA and ClsA, and a xylanase, Xyn, must be acting together on their respective components of the cell wall, the cellulose and xylan, to efficiently degrade the highly complex structure to a level that is sensed as an alarming signal by the host, to initiate the activation of defense responses. In this connection, it is pertinent to note that ClsA is an endoglucanase and that CbsA is an exoglucanase. The cooperative action of endo- and exoacting glycosyl hydrolases in efficient degradation of cellulose is very well demonstrated (Nidetzky et al. 1995; Woodward 1991; Zhou and Ingram 2000). Synergism and cooperativity among different groups of CWDEs is also documented. Palva and coworkers (Vidal et al. 1998) have shown that treatment of tobacco plants with combinations of pectic and cellulase enzymes of Erwinia carotovora subsp. carotovora induced pathogenesisrelated $\beta-1,3$ glucanase gene expression to a higher extent than treatments with individual enzymes. Interestingly, combinations of the same class of enzymes, such as pectinases (PehA + PelA/D) and cellulases (CelV1 + CelS), did not result in such an additive effect. This suggested that pectic enzymes and cellulases cooperate in eliciting the induction of defense genes in response to Erwinia carotovora subsp. carotovora (Vidal et al. 1998). Similarly cellulosomal xylanase XynA and cellulase from Clostridium cellulovorans were found to degrade corn cell walls synergistically (Murashima et al. 2003).

The model we propose is that action of multiple CWDEs is required to release the elicitors from the complex structural barrier of the plant cell. Collective action of key categories of CWDEs, like cellulases and xylanases, which act on the main components of the rice cell wall, may be absolutely required to bring down the complexity to a level that is sensed by the plant as a danger signal. In the absence of even a single major CWDE, proper degradation of the cell wall will not occur and, thus, DAMP-triggered immunity is not mounted. What could be the identity of the DAMP released from rice cell walls? Oligomers of glucose and xylose, the constituents of the cellulose and xylan, respectively, could be elicitor molecules that will be perceived by rice as DAMPs. Further experiments are required to determine the exact nature of one or more DAMPs that are released by action of ClsA, CbsA, and Xyn on rice tissues.

\section{MATERIALS AND METHODS}

\section{Bacterial strains, plasmids, primers and culture media used.}

Bacterial strains and plasmids used in the study are listed in Tables 1 and 2, respectively. Primers used in the study are listed in Supplementary Table S1. X. oryzae pv. oryzae strains were grown at $28^{\circ} \mathrm{C}$ in peptone sucrose (PS) media. Escherichia coli strains were grown in Luria Bertani media at $37^{\circ} \mathrm{C}$, as previously described (Ray et al. 2000). X. oryzae pv. oryzae strains carrying the plasmid pK18mobsacB integrated in their genomes (the single crossovers/integrants) were grown in $0.5 \%$ peptone and $0.3 \%$ beef extract-containing medium (nutrient agar/broth medium) instead of PS medium, as these strains are sensitive to sucrose. The concentrations of antibiotics used were: rifampin, $50 \mu \mathrm{g} / \mathrm{ml}$; ampicillin, $50 \mu \mathrm{g} / \mathrm{ml}$; spectinomycin, $50 \mu \mathrm{g} / \mathrm{ml}$; kanamycin, $25 \mu \mathrm{g} / \mathrm{ml}$ for $E$. coli and $15 \mu \mathrm{g} / \mathrm{ml}$ for $X$. oryzae pv. oryzae.

Table 1. List of bacterial strains used in this study

\begin{tabular}{|c|c|c|}
\hline Strain & Relevant characteristics & Reference/source \\
\hline \multicolumn{3}{|l|}{ Escherichia coli strains } \\
\hline $\mathrm{DH} 5 \alpha$ & $\begin{array}{l}\left.\lambda^{-} \text {f80d lacZDM15 D(lacZYA-argF }\right) \text { U169 recAl endA hsdR17 } \\
\left(\mathrm{r}_{\mathrm{K}}^{-} \mathrm{m}_{\mathrm{K}}^{-}\right) \text {supE44 thi-1 gyrA relA1 }\end{array}$ & Invitrogen \\
\hline S17-1 & RP4-2 Tc::Mu-Km::Tn7 pro hsdR recA Tra+ used as mobilizing strain & Simon et al. 1983 \\
\hline \multicolumn{3}{|c|}{ Xanthomonas oryzae pv. oryzae strains } \\
\hline BXO1 & Wild type; Indian isolate & Laboratory collection \\
\hline BXO43 & rif-2; derivative of $\mathrm{BXO} 1$ & Laboratory collection \\
\hline $\mathrm{T}_{3} \mathrm{SS}^{-}$ & hrpB6::bla rif-2; $\mathrm{HR}^{-}, \mathrm{Ap}^{\mathrm{r}}$ derivative of $\mathrm{BXO} 43$ & Jha et al. 2007 \\
\hline$c b s A^{-} \mathrm{T}_{3} \mathrm{SS}^{-}$ & $\Delta c b s A::$ rif-2; $\mathrm{Ap}^{\mathrm{r}}$ derivative of $\mathrm{T} \mathrm{SS}^{-}$ & This study \\
\hline$c b s A^{-} \mathrm{T}_{3} \mathrm{SS}^{-} / \mathrm{pHM} 1$ & $c b s A^{-} \mathrm{T} 3 \mathrm{SS}^{-} / \mathrm{pHM} 1 ;$ rif- $2 ; \mathrm{Ap}^{\mathrm{r}}, \mathrm{Sp}^{\mathrm{r}} ;$ derivative of $c b s A^{-} \mathrm{T}^{2} \mathrm{SS}^{-}$ & This study \\
\hline$c b s A^{-} \mathrm{T} 3 \mathrm{SS}^{-} / \mathrm{pHM} 1:: c b s A$ & $c b s A^{-} \mathrm{T} 3 \mathrm{SS}^{-} / \mathrm{pHM} 1:: c b s A ;$ rif-2; $\mathrm{Ap}^{\mathrm{r}}, \mathrm{Sp}^{\mathrm{r}}$; derivative of $c b s A^{-} \mathrm{T}_{3} \mathrm{SS}^{-}$ & This study \\
\hline$c l s A^{-} \mathrm{T}_{3} \mathrm{SS}^{-}$ & $\Delta c l s A::$ rif- $2 ; \mathrm{Ap}^{\mathrm{r}}$ derivative of $\mathrm{T}_{3} \mathrm{SS}^{-}$ & This study \\
\hline$c l s A^{-} \mathrm{T} 3 \mathrm{SS}^{-} / \mathrm{pHM} 1$ & $c l s A^{-} \mathrm{T}_{3} \mathrm{SS}^{-} / \mathrm{pHM} 1 ;$ rif- $2 ; \mathrm{Ap}^{\mathrm{r}}, \mathrm{Sp}^{\mathrm{r}} ;$ derivative of $c l s A^{-} \mathrm{T}_{3} \mathrm{SS}^{-}$ & This study \\
\hline$c l s A^{-} \mathrm{T}_{3 \mathrm{SS}}^{-} / \mathrm{pHM} 1:: c l s A$ & $c l s A^{-} \mathrm{T} 3 \mathrm{SS}^{-} / \mathrm{pHM} 1:: c l s A ;$ rif-2; $\mathrm{Ap}^{\mathrm{r}}, \mathrm{Sp}^{\mathrm{r}} ;$ derivative of $c l s A^{-} \mathrm{T} 3 \mathrm{SS}^{-}$ & This study \\
\hline$x y n^{-} \mathrm{T}_{3} \mathrm{SS}^{--}$ & $\Delta x y n:$ rif- $2 ; \mathrm{Ap}^{\mathrm{r}}$ derivative of $\mathrm{T}_{3} \mathrm{SS}^{-}$ & This study \\
\hline$x y n^{-} \mathrm{T}_{3 \mathrm{SS}} / \mathrm{pHM} 1$ & $x y n^{-} \mathrm{T} 3 \mathrm{SS}^{-} / \mathrm{pHM} 1 ;$ rif- $2 ; \mathrm{Ap}^{\mathrm{r}}, \mathrm{Sp}^{\mathrm{r}} ;$ derivative of $x y n^{-} \mathrm{T}_{3 \mathrm{SS}^{-}}$ & This study \\
\hline$x y n^{-} \mathrm{T}_{3 \mathrm{SS}}{ }^{-} / \mathrm{pHM} 1:: x y n$ & $x y n^{-} \mathrm{T}_{3 \mathrm{SS}}{ }^{-} / \mathrm{pHM} 1:$ :xyn; rif-2; $\mathrm{Ap}^{\mathrm{r}}, \mathrm{Sp}^{\mathrm{r}} ;$ derivative of $x y n^{-} \mathrm{T} \mathrm{SS}^{-}$ & This study \\
\hline$p g l A^{-} \mathrm{T} 3 \mathrm{SS}^{-}$ & $\operatorname{pglA}^{-} \mathrm{T} 3 \mathrm{SS}^{-}:: \mathrm{pK} 18 m o b$ rif-2; $\mathrm{Km}^{\mathrm{r}} ; \mathrm{pglA}^{-} ; \mathrm{Km}^{\mathrm{r}}, \mathrm{Ap}^{\mathrm{r}}$ derivative of $\mathrm{T}^{2} \mathrm{SS}^{-}$ & This study \\
\hline $\operatorname{pglA}^{-} \mathrm{T} 3 \mathrm{SS}^{-} / \mathrm{pHM} 1$ & $p g l A^{-} \mathrm{T} 3 \mathrm{SS}^{-} / \mathrm{pHM} 1 ;$ rif- $2 ; \mathrm{Km}^{\mathrm{r}}, \mathrm{Ap}^{\mathrm{r}}, \mathrm{Sp}^{\mathrm{r}} ;$ derivative of $p g l A^{-} \mathrm{T} 3 \mathrm{SS}^{-}$ & This study \\
\hline$p g l A^{-} \mathrm{T}_{3} \mathrm{SS}^{-} / \mathrm{pHM} 1: \mathrm{pglA}$ & pglA ${ }^{-} \mathrm{T} 3 \mathrm{SS}^{-} / \mathrm{pHM} 1:: p g l A ;$ rif- $2 ; \mathrm{Km}^{\mathrm{r}}, \mathrm{Ap}^{\mathrm{r}}, \mathrm{Sp}^{\mathrm{r}} ;$ derivative of $p g l A^{-} \mathrm{T}_{3} \mathrm{SS}^{-}$ & This study \\
\hline $\operatorname{lip} A^{-} \mathrm{T}_{3} \mathrm{SS}^{-}$ & $\Delta l i p A::$ rif- $2 ; \mathrm{Ap}^{\mathrm{r}}$ derivative of $\mathrm{T} \mathrm{SS}^{-}$ & This study \\
\hline lipA ${ }^{-} \mathrm{T} 3 \mathrm{SS}^{-} / \mathrm{pHM} 1$ & lipA ${ }^{-} \mathrm{T} 3 \mathrm{SS}^{-} / \mathrm{pHM} 1 ;$ rif- $2 ; \mathrm{Ap}^{\mathrm{r}}, \mathrm{Sp}^{\mathrm{r}} ;$ derivative of lipA $^{-} \mathrm{T} 3 \mathrm{SS}^{-}$ & This study \\
\hline lipA ${ }^{-} \mathrm{T} 3 \mathrm{SS}^{-} / \mathrm{pHM} 1:: l i p A$ & 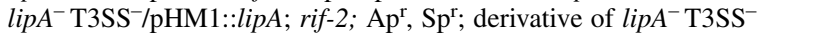 & This study \\
\hline
\end{tabular}


Molecular biology and microbiology techniques.

Genomic DNA isolation was performed as described by Leach et al. (1990). Plasmid DNA was isolated by the alkaline lysis method (Sambrook et al. 1989) or by using a Qiagen plasmid mini/midi kit. Phusion polymerase (Finnzymes) was used for polymerase chain reaction (PCR) amplification in applications that required high-fidelity DNA synthesis, while Taq polymerase was used for all other applications. Restriction digestions were done with enzymes from New England Biolabs. PCR products and restriction enzyme-digested DNA fragments were purified using a QIAquick PCR purification kit and a QIAquick nucleotide removal kit (Qiagen), respectively. Other techniques, such as ligation with T4 DNA ligase, agarose gel electrophoresis, and transformation of $E$. coli, were performed as described previously (Sambrook et al. 1989). Plasmids were transferred from $E$. coli to $X$. oryzae pv. oryzae, using either broad host-range mobilizing strain S17-1 (Simon et al. 1983) via biparental matings or electroporation (Ray et al. 2000; Subramoni and Sonti 2005).

\section{Sequencing and analysis.}

DNA sequencing was performed using an ABI Prism 3700 automated DNA sequencer (Perkin-Elmer). The sequences were analyzed using the BLAST algorithm in the National Center for Biotechnology Information database (Altschul et al. 1990).

Generation of in frame deletion mutants of $\operatorname{cbs} A, \operatorname{lip} A$, $c l s A$, and $x y n$ in a genetic background

of $\mathrm{T3SS}^{-}$of $X$. oryzae pv. oryzae.

Using genomic DNA of $X$. oryzae pv. oryzae wt strain BXO43 as template and two primer pairs for each gene, F1/R1 and F2/R2, two PCR fragments were amplified (the R1 and F2 primers designed for all the genes contained engineered $\mathrm{XbaI}$ restriction enzyme site at its $5^{\prime}$ end, whereas F1and R2 primers for all the genes contained engineered HindIII restriction enzyme site at its $5^{\prime}$ end). The PCR-amplified fragments were gel-extracted, digested with $X b a \mathrm{I}$, and ligated with each other, using T4 DNA ligase. To amplify the ligated fragment, the ligation mixture was used as template and primers F1 and R2 were used, so that the ligated fragment contained HindIII restriction enzyme sites at its $5^{\prime}$ and $3^{\prime}$ ends. The ligated fragment after digestion with the HindIII enzyme was cloned into the HindIII site of the vector pK18mobsacB (Schäfer et al. 1994). The recombinant plasmids pK18mobsacB with the ligated fragment were then transformed into S17-1 (Simon et al. 1983). Biparental matings were then set up between the S17-1 E. coli cells containing the construct and the $\mathrm{T}_{3} \mathrm{SS}^{-}$of $X$. oryzae $\mathrm{pv}$. oryzae. $\mathrm{T} \mathrm{SS}^{-}$strains that received and integrated the plasmid into the genome by homologous recombination were selected by kanamycin resistance. Integration of plasmids at the correct locus in $X$. oryzae pv. oryzae genome was confirmed by PCR, using a pair of primers, ICF and ICR. Sucrose sensitivity of these single recombinants was also tested. Single recombinants in $\mathrm{T}_{3} \mathrm{SS}^{-}$background that were ampicillin- and kanamycinresistant and sucrose-sensitive were grown in liquid media containing $0.3 \%$ beef extract and $0.5 \%$ peptone without kanamycin. Subculturing was done twice and, finally, cultures were plated on $1 \%$ PSA and ampicillin-containing plates. Putative double recombinants, which include mutants and wt cells that are sucrose- and ampicillin-resistant but kanamycin-sensitive, were isolated. They were confirmed by PCR, digestion of amplified PCR product with $\mathrm{XbaI}$ and sequencing of the PCR product, and by checking the protein profile of the extracellular fractions for the loss of the corresponding protein, by SDS PAGE.

\section{Generation of the $\mathrm{pglA}^{-} \mathrm{T}_{3 \mathrm{SS}}^{-}$strain of $X$. oryzae pv. oryzae.}

A pglA $\mathrm{T}^{-} \mathrm{SS}^{-}$strain of $X$. oryzae pv. oryzae was generated by gene disruption, using homologous plasmid integration of a suicide vector pK18mob. A 759-bp internal fragment of the pglA gene was amplified by PCR, using genomic DNA of a $X$. oryzae pv. oryzae wt strain and the gene-specific PglAFP/PglARP oligonucleotide primer pair. This fragment was cloned into the $X b a I-$ and HindIII-digested pK18mob cloning vector to obtain recombinant plasmid. The plasmid was then electroporated into $\mathrm{T}_{3} \mathrm{SS}^{-}$and clones were selected for kanamycin resistance to obtain a $\mathrm{pglA^{- }}$ mutant by plasmid integration. Gene disruption was confirmed by PCR, using gene-specific flanking primers PglA ICF and PglA ICR in combination with vectorspecific primers M13F and M13R, and the sequencing of PCR products. The $p g l A$ gene fragment was cloned in the same transcriptional orientation as the lacZ promoter of the pK18mob vector, so that mutation caused by vector integration did not have a polar effect on downstream genes due to activity of the outwardly directed lacZ promoter.

\section{Generation of complementing strains.}

For $c b s A^{-} \mathrm{T}_{3} \mathrm{SS}^{-}$complementation, a 1,782-bp DNA fragment containing the full length of the $c b s A$ gene was amplified by PCR, using primers CBCF and CBCR and genomic DNA of BXO43 as template. The PCR-amplified DNA fragment was cloned as a HindIII-EcoRI fragment into the broad host-range vector pHM1 (Innes et al. 1988), to create the recombinant plasmid pTC1. The pTC1 plasmid and pHM1 vector were individually introduced into the $c b s A^{-} \mathrm{T}_{3} \mathrm{SS}^{-}$strain by electroporation, and the recombinants were isolated by selection for spectinomycin resistance. The presence of pTLC1 was confirmed by PCR, using $c b s A$ gene-specific primers $\mathrm{CBCF}$ and $\mathrm{CBCR}$ and universal primers M13F and M13R and the sequencing of PCR

Table 2. List of plasmids used in this study

\begin{tabular}{|c|c|c|}
\hline Plasmids & Relevant characteristics & Reference/source \\
\hline pK18mobsacB & $\begin{array}{l}\text { Allelic exchange suicide vector SacB derivative of pK18mob; sacB } \mathrm{Tra}^{-} \mathrm{Mob}^{+} \text {, } \\
\mathrm{km}^{\mathrm{r}} \text { does not replicate in Xanthomonas oryzae pv. oryzae }\end{array}$ & Schäfer et al. 1994 \\
\hline pK18mob & pUC18 derivative; $\mathrm{Mob}^{+} \mathrm{Tra}^{-} \mathrm{Km}^{\mathrm{r}}$; does not replicate in X. oryzae pv. oryzae & Schäfer et al. 1994 \\
\hline pHM1 & Broad-host-range cosmid vector $(13.3 \mathrm{~kb}) ; \mathrm{Sp}^{\mathrm{r}}$ & Innes et al. 1988 \\
\hline pTL1 & pK18mobsacB+1,373-bp of $\mathrm{A}+\mathrm{C}$ fragment of $c b s A$ gene & This study \\
\hline pTL2 & pK18mobsacB+1,357-bp of $\mathrm{A}+\mathrm{C}$ fragment of $c l s A$ gene & This study \\
\hline pTL3 & pK18mobsacB+1,719-bp of $\mathrm{A}+\mathrm{C}$ fragment of $x y n$ gene & This study \\
\hline pTL4 & pK18mob+759-bp of internal fragment of pgla gene & This study \\
\hline pTL5 & pK18mobsacB $+1,481$ bp of $\mathrm{A}+\mathrm{C}$ fragment of lipA gene & This study \\
\hline pTLC1 & pHM1+1,782-bp gene fragment containing 1,701-bp cbsA gene & This study \\
\hline pTLC2 & pHM1+1,685-bp gene fragment containing 1,449-bp clsA gene & This study \\
\hline pTLC3 & pHM1+1,017-bp gene fragment containing 978-bp xyn gene & This study \\
\hline pTLC4 & pHM1+1,853-bp gene fragment containing 1,671-bp pglA gene & This study \\
\hline pGJ5 & pHM1+1,511-bp gene fragment containing 1,281-bp lipA gene & Aparna et al. 2007 \\
\hline
\end{tabular}


products. Similarly for $c l s A^{-} \mathrm{T}_{3 S^{-}}$and $x y n^{-} \mathrm{T}_{3} \mathrm{SS}^{-}$strain complementation, a 1,685-bp DNA fragment containing the $c l s A$ gene and a 1,017-bp DNA fragment containing xyn gene were PCRamplified and cloned into HindIII-SacI sites of pHM1 vector to generate pTLC2 and pTLC3 plasmids, respectively. For $p g l A^{-} \mathrm{T} \mathrm{SS}^{-}$strain complementation, a 1,853-bp fragment containing the pglA gene was PCR-amplified and cloned into HindIIIEcoRI sites of pHM1 vector to generate pTLC4. For lipA ${ }^{-} \mathrm{T}_{3} \mathrm{SS}^{-}$ strain complementation, pGJ5 (pHM1+1,511 bp of DNA fragment containing the lipA gene) was used. These recombinant plasmids were moved into their respective mutants. Empty pHM1 vector was also introduced into mutant strains. Spectinomycin-resistant putative complementation clones were confirmed by PCR and sequencing and were shown to restore either enzymatic activity or protein production.

\section{Protein purification and activity assays.}

Saturated cultures of $X$. oryzae pv. oryzae strains were pelleted by centrifugation at $4^{\circ} \mathrm{C}$. Proteins in the culture supernatant were precipitated by ammonium sulfate $(55 \%)$ and suspended in $0.01 \mathrm{M}$ potassium phosphate buffer $(\mathrm{pH} 6.0)$. Excess salt is removed by dialysis. Total protein $(30 \mu \mathrm{g})$ of each strain was loaded and separated by SDS-PAGE. Cellulase activity in the extracellular fractions of $X$. oryzae pv. oryzae strains was checked on $1.2 \%$ agarose suspension containing $0.2 \%$ carboxymethyl cellulose solidified in petri plates, as described earlier (Jha et al. 2007). Pectinase activity was performed by growing the $X$. oryzae pv. oryzae strains on PSA plates containing $0.1 \%$ Na-PGA as substrate and staining with $0.05 \%$ ruthenium red dye solution in water. Xylanase and lipase activities were performed as described earlier (Rajeshwari et al. 2005).

\section{Innate immune responses in rice: $\mathrm{PCD}$ assay in rice roots.}

Rice (TN-1) seeds were surface-sterilized with sodium hypochlorite and were germinated on $0.5 \%$ sterile agar in petri dishes for 3 to 4 days at $28^{\circ} \mathrm{C}$. Root tips, 1 to $2 \mathrm{~cm}$ long, were treated with cultures of $X$. oryzae pv. oryzae strains of an optical density (OD) of 1.5 in $1 \times$ phosphate buffered saline. After incubation for $16 \mathrm{~h}$, roots were washed with sterile MQ water and were stained with $1 \mathrm{mg}$ of PI solution per milliliter for $1 \mathrm{~h}$. The roots were mounted on a microscopic slide in $50 \%$ glycerol. Longitudinal optical sections ( $1 \mu \mathrm{m}$ thick) were acquired on a Zeiss LSM-510 Meta confocal microscope using 63× oil immersion (NA 1.4). A HeNe laser at $543 \mathrm{~nm}$ excitation and emission above $560 \mathrm{~nm}$ (LP) was used to detect PI internalization. All images were analyzed using LSM software and were further edited using Photoshop (Adobe).

\section{Innate immune responses in rice: callose deposition assay in rice leaves.}

TN-1 rice seedlings about 10 to 15 days old were infiltrated with cultures of $X$. oryzae pv. oryzae strains of OD 1.0, using a needleless syringe. After $16 \mathrm{~h}$, infiltrated zones (approximately $1 \mathrm{~cm}$ long) were cut from the leaf and were destained by heating at $60^{\circ} \mathrm{C}$ with alcohol and, then, were stained with $0.05 \%$ aniline blue solution in water overnight and were analyzed under an Axioplan2 epifluroscence microscope, using a blue filter and $\times 10$ objective.

\section{ACKNOWLEDGMENTS}

We thank M. Dow for providing the plasmid pK18mobsacB. L. Tayi acknowledges a fellowship from the Indian Council of Medical Research. This work was supported by the XIIth five year plan project, Plant-Microbe and Soil Interactions (BSC0117) of the Council of Scientific and Industrial Research, and J C Bose fellowship to R. V. Sonti. We thank A. Pandey for his guidance in molecular biology experiments. We acknowledge the help of D. Sinha and M. Dasgupta for their help in microscopic studies.

\section{LITERATURE CITED}

Alfano, J. R., and Collmer, A. 2004. TYPE III SECRETION SYSTEM EFFECTOR PROTEINS: Double agents in bacterial disease and plant defense. Annu. Rev. Phytopathol. 42:385-414.

Altschul, S. F., Gish, W., Miller, W., Myers, E. W., and Lipman, D. J. 1990. Basic local alignment search tool. J. Mol. Biol. 215:403-410.

Aparna, G., Chatterjee, A., Jha, G., Sonti, R. V., and Sankaranarayanan, R. 2007. Crystallization and preliminary crystallographic studies of LipA, a secretory lipase/esterase from Xanthomonas oryzae pv. oryzae. Acta Crystallogr. Sect. F Struct. Biol. Cryst. Commun. 63:708-710.

Barras, F., van Gijsegem, F., and Chatterjee, A. K. 1994. Extracellular enzymes and pathogenesis of soft-rot Erwinia. Annu. Rev. Phytopathol. 32:201-234.

Bartetzko, V., Sonnewald, S., Vogel, F., Hartner, K., Stadler, R., Hammes, U. Z., and Börnke, F. 2009. The Xanthomonas campestris pv. vesicatoria type III effector protein XopJ inhibits protein secretion: Evidence for Interference with cell wall-associated defense responses. Mol. PlantMicrobe Interact. 22:655-664.

Benedetti, M., Pontiggia, D., Raggi, S., Cheng, Z., Scaloni, F., Ferrari, S., Ausubel, F. M., Cervone, F., and De Lorenzo, G. 2015. Plant immunity triggered by engineered in vivo release of oligogalacturonides, damageassociated molecular patterns. Proc. Natl. Acad. Sci. U.S.A. 112:5533-5538

Bestwick, C. S., Bennett, M. H., and Mansfield, J. W. 1995. Hrp mutant of Pseudomonas syringae pv. phaseolicola induces cell wall alterations but not membrane damage leading to the hypersensitive reaction in lettuce. Plant Physiol. 108:503-516.

Büttner, D., and He, S. Y. 2009. Type III protein secretion in plant pathogenic bacteria. Plant Physiol. 150:1656-1664.

Chisholm, S. T., Coaker, G., Day, B., and Staskawicz, B. J. 2006. Hostmicrobe interactions: Shaping the evolution of the plant immune response. Cell 124:803-814.

Darvill, A. G., and Albersheim, P. 1984. Phytoalexins and their elicitors-a defense against microbial infection in plants. Annu. Rev. Plant Physiol. 35:243-275.

Enkerli, J., Felix, G., and Boller, T. 1999. The enzymatic activity of fungal xylanase is not necessary for its elicitor activity. Plant Physiol. 121:391-398.

Galletti, R., De Lorenzo, G., and Ferrari, S. 2009. Host-derived signals activate plant innate immunity. Plant Signal. Behav. 4:33-34.

Gough, C. L., Dow, J. M., Barber, C. E., and Daniels, M. J. 1988. Cloning of two endoglucanase genes of Xanthomonas campestris pv. campestris: Analysis of the role of the major endoglucanase in pathogenesis. Mol. Plant-Microbe Interact 1:275-281.

Hauck, P., Thilmony, R., and He, S. Y. 2003. A Pseudomonas syringae type III effector suppresses cell wall-based extracellular defense in susceptible Arabidopsis plants. Proc. Natl. Acad. Sci. U.S.A. 100:8577-8582.

Innes, R. W., Hirose, M. A., and Kuempel, P. 1988. Induction of nitrogenfixing nodules on clover requires only 32 kilobase pairs of DNA from the Rhizobium trifolii symbiosis plasmid. J. Bacteriol. 170:3793-3802.

Jha, G., Rajeshwari, R., and Sonti, R. V. 2005. Bacterial type two secretion system secreted proteins: Double-edged swords for plant pathogens. Mol. Plant-Microbe Interact. 18:891-898.

Jha, G., Rajeshwari, R., and Sonti, R. V. 2007. Functional interplay between two Xanthomonas oryzae pv. oryzae secretion systems in modulating virulence on rice. Mol. Plant-Microbe Interact. 20:31-40.

Jones, J. D. G., and Dangl, J. L. 2006. The plant immune system. Nature 444:323-329

Kang, Y., Huang, J., Mao, G., He, L., and Schell, M. A. 1994. Dramatically reduced virulence of mutants of Pseudomonas solanacearum defective in export of extracellular proteins across the outer membrane. Mol. Plant-Microbe Interact. 7:370-377.

Keshavarzi, M., Soylu, S., Brown, I., Bonas, U., Nicole, M., Rossiter, J., and Mansfield, J. 2004. Basal defenses induced in pepper by lipopolysaccharides are suppressed by Xanthomonas campestris pv. vesicatoria. Mol. Plant-Microbe Interact. 17:805-815.

Leach, J. E., White, F. F., Rhoads, M. L., and Leung, H. 1990. A repetitive DNA sequence differentiates Xanthomonas campestris pv. oryzae from other pathovars of X. campestris. Mol. Plant-Microbe Interact 3:238-246.

Lee, B.-M., Park, Y.-J., Park, D.-S., Kang, H.-W., Kim, J.-G., Song, E.-S., Park, I.-C., Yoon, U.-H., Hahn, J.-H., Koo, B.-S., Lee, G.-B., Kim, H., Park, H.-S., Yoon, K.-O., Kim, J.-H., Jung, C.-h., Koh, N.-H., Seo, J.-S., and Go, S.-J. 2005. The genome sequence of Xanthomonas oryzae pathovar oryzae KACC10331, the bacterial blight pathogen of rice. Nucleic Acids Res. 33:577-586.

Li, X., Lin, H., Zhang, W., Zou, Y., Zhang, J., Tang, X., and Zhou, J.-M 2005. Flagellin induces innate immunity in nonhost interactions that is suppressed by Pseudomonas syringae effectors. Proc. Natl. Acad. Sci. U.S.A. 102:12990-12995. 
Ma, Y., Han, C., Chen, J., Li, H., He, K., Liu, A., and Li, D. 2015. Fungal cellulase is an elicitor but its enzymatic activity is not required for its elicitor activity. Mol. Plant Pathol. 16:14-26.

Murashima, K., Kosugi, A., and Doi, R. H. 2003. Synergistic effects of cellulosomal xylanase and cellulases from Clostridium cellulovorans on plant cell wall degradation. J. Bacteriol. 185:1518-1524.

Nidetzky, B., Steiner, W., and Claeyssens, M. 1995. Synergistic interaction of cellulases from Trichoderma reesei during cellulose degradation. Pages 90-112 in: Enzymatic Degradation of Insoluble Carbohydrates. ACS Symposium Series 618. J. N. Saddler and M. E. Himmel, eds. American Chemical Society, Washington, D.C.

Rajeshwari, R., Jha, G., and Sonti, R. V. 2005. Role of an in plantaexpressed xylanase of Xanthomonas oryzae pv. oryzae in promoting virulence on rice. Mol. Plant-Microbe Interact. 18:830-837.

Ray, S. K., Rajeshwari, R., and Sonti, R. V. 2000. Mutants of Xanthomonas oryzae pv. oryzae deficient in general secretory pathway are virulence deficient and unable to secrete xylanase. Mol. Plant-Microbe Interact. 13:394-401.

Ron, M., and Avni, A. 2004. The receptor for the fungal elicitor ethyleneinducing xylanase is a member of a resistance-like gene family in tomato. Plant Cell 16:1604-1615.

Ryan, C. A., and Farmer, E. E. 1991. Oligosaccharide signals in plants: A current assessment. Annu. Rev. Plant Biol. 42:651-674.

Sambrook, J., Fritsch, E.F., and Maniatis, T. 1989. Molecular Cloning. Cold Spring Harbor Laboratory Press, New York.

Sato, C., Oka, N., Nabeta, K., and Matsuura, H. 2011. Cellulase applied to the leaves of sweet pepper (Capsicum annuиm L. var. grossum) upregulates the production of salicylic and azelaic acids. Biosci. Biotechnol. Biochem. 75:761-763.
Schäfer, A., Tauch, A., Jäger, W., Kalinowski, J., Thierbach, G., and Pühler, A. 1994. Small mobilizable multi-purpose cloning vectors derived from the Escherichia coli plasmids pK18 and pK19: Selection of defined deletions in the chromosome of Corynebacterium glutamicum. Gene 145:69-73.

Shibuya, N., and Minami, E. 2001. Oligosaccharide signalling for defence responses in plant. Physiol. Mol. Plant Pathol. 59:223-233.

Simon, R., Priefer, U., and Pühler, A. 1983. A broad host range mobilization system for in vivo genetic engineering: Transposon mutagenesis in gram negative bacteria. Nat. Biotechnol. 1:784-791.

Sinha, D., Gupta, M. K., Patel, H. K., Ranjan, A., and Sonti, R. V. 2013. Cell wall degrading enzyme induced rice innate immune responses are suppressed by the type 3 secretion system effectors XopN, XopQ, XopX and XopZ of Xanthomonas oryzae pv. oryzae. PLoS One 8: e75867.

Subramoni, S., and Sonti, R. V. 2005. Growth deficiency of a Xanthomonas oryzae pv. oryzae fur mutant in rice leaves is rescued by ascorbic acid supplementation. Mol. Plant-Microbe Interact. 18:644-651.

Vidal, S., Eriksson, A. R. B., Montesano, M., Denecke, J., and Palva, E. T. 1998. Cell wall-degrading enzymes from Erwinia carotovora cooperate in the salicylic acid-independent induction of a plant defense response. Mol. Plant-Microbe Interact. 11:23-32.

Woodward, J. 1991. Synergism in cellulase systems. Bioresour. Technol. 36:67-75.

Zhou, S., and Ingram, L. O. 2000. Synergistic hydrolysis of carboxymethyl cellulose and acid-swollen cellulose by two endoglucanases (CelZ and CelY) from Erwinia chrysanthemi. J. Bacteriol. 182: 5676-5682. 